\title{
9 Disaster Response and Emergency Risk Management in Ethiopia
}

\author{
JOHN GRAHAM*, SHAHIDUR RASHID, \\ AND MEHRAB MALEK
}

Agrarian communities dependent on rainfall are vulnerable to production shortfalls due to drought and other climatic shocks. The human suffering caused by such shocks is often amplified due to deficiencies in market fundamentals, such as roads, information, and risk management institutions. This has been the case in Ethiopia for several centuries, dating back to medieval chronicles of the ninth century (Pankhurst 1985; von Braun, Teklu, and Webb 1998), when droughts caused widespread food insecurities and, in extreme cases, famine.

However, sharp reductions in food production need not cause famines, nor are they the only cause of famines. Entitlement failures (households' loss of the ability to acquire sufficient food through their own production, other income, or transfers) can also result in widespread hunger even when the country's total food supply is adequate (Sen 1981). Moreover, inadequate consumption of macronutrients (calories, proteins, and fats and oils) or micronutrients (such as iron, vitamin A, and iodine) or insufficient absorption of nutrients due to disease or other health problems can result in severe malnutrition even when overall volumes of food consumption seem adequate (Bouis and Haddad 1992). Thus, food security can be more accurately viewed as a combination of availability of, access to, and use of food and nutrients (Devereux and Maxwell 2001). Both public policies and private responses can play a role in mitigating the dire consequences of shocks related to food availability, access, or entitlements and preventing widespread consumption declines. Therefore, it is important to understand how and why various aspects of food security deteriorate to cause famine, as well as what medium- or long-term policy forces are behind those outcomes. The literature has already indicated that the complex causes of famine include agricultural and overall economic development policies, instability and military conflict, market structure and performance, and the effectiveness of response by both the government and nongovernmental organizations (NGOs) (Webb and von Braun 1994; Devereux and Maxwell 2001). However, there remains a continued need for an examination of the types of policies and pro-

*This chapter reflects the author's viewpoint and does not necessarily reflect the views of the U.S. government. 
grams that can help combat famines that occur as a result of drought and other shocks. This chapter presents an account of food shortages and policy responses in Ethiopia over the past four decades, as well as the perspectives of an insider to the policy process related to donor and government agencies. The objectives of this chapter are to review the history of famine in Ethiopia in the context of responses by the different regimes, donor agencies, and NGOs; discuss the major reforms that have taken place over the decades; and finally review the current food security environment in Ethiopia. One significant observation that underlies this chapter is that since the 1990s there has not been another widespread famine causing large-scale deaths in Ethiopia. Thus, the country's recent history has diverged sharply from the pre-1990s legacy.

\section{The History of Food Insecurity and Famine in Ethiopia through 1992}

The most severe drought-related famines in Ethiopia were recorded in Tigray in 1958, in Wollo in 1966 and 1973, and in Hararghe, Tigray, and Wollo in 1983. The estimated deaths from these famines vary, but commonly cited numbers are 100,000 deaths in 1958, an estimated 250,000 deaths in 1966 and 1973, and 590,000 deaths in 1984 (Africa Watch 1991). ${ }^{1}$ Table 9.1 presents an overview of these famines and food shortfalls in Ethiopia. The occurrence of these four famines in such a short interval resulted in a common perception that rain shortfalls and subsequent famines would be on a 7- to 11-year cycle, which subsequently has not proven to be true. ${ }^{2}$ In the last two decades, rain failures have caused grave food shortages in different parts of Ethiopia; fortunately they have not caused widespread famines, proving that appropriate policies and institutions can play important roles in averting famines.

\section{Famine before 1972}

The first and worst of the famines in "modern" Ethiopian history was the rinderpest famine of 1888-92. Caused by the introduction of new livestock into neighboring Eritrea, rinderpest, an infectious viral disease found among cattle, was introduced to the vulnerable, unexposed native cattle populations. With no prior exposure, Ethiopian cattle were unable to fight off the disease. Livestock mortality reached immense proportions. Although estimates vary, some claim that 90 percent of the cattle of Ethiopia perished, and Robert Skinner, the first US envoy to Ethiopia, later reported that not more than 7 or 8 percent were

1. For example, von Braun, Teklu, and Webb (1998) report that nearly 1 million people died during the 1983-84 famine.

2. Rainfall remains highly variable, however, and there are indications that rainfall is increasingly affected by climate change and is becoming less reliable. In particular, the early belg rains from February to May across much of the highland areas of Ethiopia were less than expected in recent years, while rainfall is declining in the south of the country-particularly the southeast (Eilerts 2009). 
TABLE 9.1 A historical account of Ethiopian famines and major food shortages, geographic locations, and attributed causes, 1888-2009

\begin{tabular}{|c|c|c|}
\hline Date & Region affected & Attributed causes and severity \\
\hline 1888-92 & Ethiopia & $\begin{array}{l}\text { Rinderpest affected the cattle population. An } \\
\text { estimated } 90 \text { percent of livestock lost, and an } \\
\text { estimated } 2 \text { million dead. }\end{array}$ \\
\hline $1957-58$ & Tigray and Wollo & Rain failure in 1957. Locusts and epidemic in 1958. \\
\hline $1964-66$ & Tigray and Wollo & $\begin{array}{l}\text { Not properly documented, but some writers have } \\
\text { argued that this crisis was worse than that in } \\
\text { 1972-74. }\end{array}$ \\
\hline $1972-74$ & Ethiopia & $\begin{array}{l}\text { A sequence of rain failures. An estimated quarter } \\
\text { million dead and } 50 \text { percent of livestock lost in } \\
\text { Tigray and Wollo. }\end{array}$ \\
\hline $1978-79$ & Southern Ethiopia & Failure of the belg rains. \\
\hline 1982 & Northern Ethiopia & Late meher rains. \\
\hline $1984-85$ & Ethiopia & $\begin{array}{l}\text { A sequence of rain failures. Eight million affected; an } \\
\text { estimated } 1 \text { million dead, and much livestock loss. }\end{array}$ \\
\hline $1987-88$ & Ethiopia & $\begin{array}{l}\text { Drought of undocumented severity in peripheral } \\
\text { regions. }\end{array}$ \\
\hline $1990-92$ & $\begin{array}{l}\text { Northern, eastern, and } \\
\text { southwestern Ethiopia }\end{array}$ & $\begin{array}{l}\text { Rain failure and regional conflicts. An estimated } \\
4 \text { million people suffered food shortage. }\end{array}$ \\
\hline 1993-94 & $\begin{array}{l}\text { Tigray, Wollo, and } \\
\text { Addis Ababa }\end{array}$ & $\begin{array}{l}\text { Due to droughts, } 4 \text { million people required food } \\
\text { assistance, including demobilized army and Somali } \\
\text { refugees. New droughts. }\end{array}$ \\
\hline $1997-2000$ & $\begin{array}{l}\text { Eritrea and northern } \\
\text { Tigray }\end{array}$ & Localized food shortages due to conflict. \\
\hline 1999-2000 & Somali region & $\begin{array}{l}\text { Food security crisis due to rain failures and decline in } \\
\text { prices of livestock, the main source of pastoralists' } \\
\text { income. }\end{array}$ \\
\hline $2002-03$ & Ethiopia & $\begin{array}{l}\text { Drought-induced crop shortages; } 12.6 \text { million people } \\
\text { were affected. }\end{array}$ \\
\hline $2008-09$ & Southern Ethiopia & Localized drought; 6.4 million people were affected. \\
\hline
\end{tabular}

SOURCES: 1888-92: Pankhurst (1964); 1957-94: Webb and von Braun (1994); 1997-2009: Dorosh, Schmidt, and Taffesse (2010).

spared (Pankhurst 1964). Unlike most of the affected Sub-Saharan African areas, Ethiopia had a long tradition of plow-based rather than hoe-based agriculture, so the country was hit doubly hard. Not only did rinderpest wipe out milk and meat production, it also wiped out crop production as plow oxen died. ${ }^{3}$ As a result, a terrible famine gripped the country. Weakened populations suc-

3. Drought may have also contributed to the mortality of livestock and crop losses (Pankhurst 1985). 
cumbed to a variety of diseases, including cholera. Rough estimates are that at least 2 million people, around one-third of the total Ethiopian population at that time, died (Pankhurst 1964; Zewde 2002). ${ }^{4}$

\section{The 1972-74 Famine}

The proximate cause of the 1972-74 famine can be identified as a sequence of rainfall failures and the consequent drought. Poor infrastructure, weak agricultural growth, and the absence of a specific disaster response strategy compounded the effects of the famine (Webb and von Braun 1994). In addition, the relief response to the crisis was seriously hampered and the impact of the famine exacerbated by government reluctance to admit the severity of the situation. ${ }^{5}$

As in all famines, the scale of deaths in 1972-74 is hard to determine, with estimates ranging from 40,000 to 80,000 in the immediate aftermath of the famine (Seaman and Holt 1975) to over 300,000 in a 1991 study (Ofcansky and Berry 1991). That famine has become one of the most studied events in humanitarian experience. Sen (1981) used it as one of the case studies in his seminal work on famine, describing the Wollo famine as an entitlement failure. He contended that there was no shortage in the overall food supply in Ethiopia, nor were there unusually high prices for food in Wollo; it was simply a case in which the poor did not have sufficient production or the money to buy food, which was exacerbated by a lack of both internal and external assistance. There is room for debate over this claim; other sources have documented large increases in grain prices (Webb and von Braun 1994) and the failure of the government to prevent the famine (de Waal 1997).

National pride and perhaps a concern that accepting outside help would diminish the standing of the government to the advantage of political opponents could explain the reluctance of the regime to accept the severity of the crisis. This was evident from an official response to the UNICEF report on the 197274 famine, which stated in clear terms that the description of the food security situation in the report was embarrassing for the country and that the government did not want any international assistance if such a description was necessary (Scholler and Brietzke 1976). For the vice minister of planning, who articulated that response, the underlying concern was the political embarrassment, not the severity of hunger and deprivation.

4. The gradual solution to the rinderpest famine was the natural selection process by which only the cattle most resistant to the disease were able to survive and reproduce. Although rinderpest remained a scourge for many decades, it never devastated the herds in the same way again. One hundred and twenty years after its arrival, rinderpest was the first animal disease to have officially been declared eliminated in Ethiopia.

5. Denial and apparent unwillingness to act were also major reasons that the droughts of 1958 and 1966 led to famines with very little organized response either from the Ethiopian government or the international community (de Waal 1997). 
It is interesting to note that the 1972-74 famine, which started with such a clear denial by the vice minister of planning, ended up launching the modern response to famines in Ethiopia in spite of government authorities rather than because of them. The famine was exposed to the international community by the BBC news when Jonathon Dimbleby received permission to film the situation on the ground in Ethiopia. When his program "The Unknown Famine" came out, it helped to instigate a heightened protest against the Haile Selassie regime, which culminated in its overthrow (Gill 2010). The government began to allow aid organizations to respond to the famine, and a worldwide response fueled NGOs to set up feeding camps where the hungry gathered, although it was already too late for many Ethiopians (Gill 1986; Zewde 2002). ${ }^{6}$

One of the positive outcomes of the 1972-74 famine was the development of the Relief and Rehabilitation Commission (RRC). Founded under the Derg regime in 1974, the RRC eventually grew to be arguably the largest and most powerful part of the Ethiopian government with the exception of the military. Fueled by genuine concern over the high number of deaths in the 1972-74 famine, the RRC was initially focused on generating information to help prevent famine. According to many existing studies, the RRC produced some of the finest analyses of poverty and famine in Ethiopia and achieved impressive standards in its implementation of relief measures (de Waal 1997). Its performance during the 1984-85 famine, however, was far less satisfactory.

\section{The 1984-85 Famine}

A BRIEF REVIEW OF CAUSES AND CONSEQUENCES. There were four broad causes of the 1984-85 famine: military conflict, drought and crop failure, government policies regarding land reform and investment, and market failures (Webb and von Braun 1994). Ongoing wars against the regime of Mengistu Haile Mariam by the Eritrean People's Liberation Front and the Tigray Peoples' Liberation Front (TPLF) not only resulted in loss of life and serious injuries but also reduced the labor force available for crop cultivation and diverted scarce resources away from needed investments in agriculture. Drought-induced crop failure and loss of livestock played major roles as well; per capita production of cereals declined from 154.1 kilograms in $1982-83$ to only 91.2 kilograms in $1985-86 .{ }^{7}$ Even with imports (including food aid) of approximately 800,000 tons per year in 1985-86 and 1986-87, per capita availability fell from 151.5 kilograms in

6. Julius Holt, formerly with Save the Children UK, recounted a similar story in which Save the Children UK finally received a visit from the emperor at a dismal feeding camp in Wollo made up of thousands of tents. The emperor arrived in his characteristic Rolls Royce, walked around part of the camp staring into the mid-distance as he was wont to do, and paused before climbing back into the car. Gazing at the rows of tents, he said to an underling, "Look at the terrible conditions these foreigners keep our people in" before leaving (Holt, pers. comm.).

7. Data, including Eritrea, from FAO (various years a). Note that the FAO reports 1983-84 production as 1983 . 
1982-83 to 100.1 kilograms in 1985-86 and 110.2 kilograms in 1986-87 (Dorosh, Schmidt, and Taffesse 2010).

Government land reform policies, including abolishing private landownership in 1975 and imposing a ceiling of 10 hectares per farm on private land access rights, were welcomed in much of central and southern Ethiopia (von Braun and Webb 1994); however, subsequent government investment in agriculture was allocated mainly to state farms and producer cooperatives instead of to independent small farmers. Finally, market restrictions (regulations and bans on interregional movement of grain and labor), requirements for licensed private traders to make 50 percent of their purchases available to the Agricultural Marketing Corporation at fixed prices, and poor market infrastructure all contributed to a lack of market integration (Dorosh, Schmidt, and Taffesse 2010).

THE POLITICAL ECONOMY OF THE FAMINE RESPONSE. The famine of 1984-85 triggered a worldwide response, arguably creating much of the international humanitarian response that exists today. The scale and publicity of the famine was a testament to failure - the failure to respond to the warnings of famine. The $\mathrm{RRC}$ had turned into a politicized body and, as a result, failed to raise the alarm before the massive famine of 1984-85. The head of the RRC during the famine, Dawit Wolde Giorgis, documented his firsthand experience in a 1989 report. He complained that the information that the RRC generated regarding the growing famine, as well as its attempts to draw Mengistu's attention to the problem, was thwarted by political considerations. This was particularly so because the famine coincided with the Derg regime's preparation for the 10-year anniversary of the birth of the "Workers and Peasants Paradise"; they did not want the embarrassment of a famine on their hands. The Derg regime, like the Haile Selassie regime, failed to act to prevent the death of "peasants" from starvation. ${ }^{8}$

The main exacerbating factor in the famine of 1984-85 was the war with Eritrean and Tigrayan insurgents, who were operating in many of the affected regions. Not only did this divert state resources and attention from humanitarian concerns to military efforts, but also food and starvation became weapons of war. In the northern areas, the government used the drought to starve out the peasantry, which they believed was supporting the insurgents. This strategy eventually backfired, leaving the government with an even more embittered peasantry, as well as insurgents greatly strengthened by the international support given to them through Sudan to get food into the stricken areas. However, the situation did not go unnoticed for long. Eventually a response to the famine

8. Nonetheless, there were efforts on the part of the RRC to warn the donor community of the impending famine even in October 1983, a full year before the famine became global news (Wolde Giorgis 2004). Note, though, that the Ethiopian government also ignored the RRC warnings, and none of these warnings was covered in the state media. 
was mounted; although late in arriving, it was massive. The major catalyst for the response was the international community, specifically the media. The BBC broke the news of the famine in October 1984, followed by a report from the Canadian Broadcasting Corporation a few days later. Once television screens worldwide were filled with images of starving masses from Korem and Mekelle, a strong international response began. ${ }^{9}$ The response was so massive that it overwhelmed any sense of resistance from Ethiopian government officials.

Responding to famines in a sovereign state does not just require overall permission from that state; it also requires a myriad of bureaucratic agreements to facilitate the arrival and movement of aid workers (not to mention rock stars), food aid, and medical aid. ${ }^{10}$ Faced with many bureaucratic hurdles in the 198485 famine (Gill 1986; Wolde Giorgis 1989), relief poured into Ethiopia in spite of ideological differences between western governments and the Derg regime. ${ }^{11}$ Having been unsuccessful in covering up the massive human suffering, the greater embarrassment to the Ethiopian government would have come from not responding. ${ }^{12}$

Much has been written about the 1984 famine, and almost everyone involved has received criticism for not doing more and better sooner. Peter Gill's A Year in the Death of Africa methodically tracks the blame for the lack of early response; in the book the World Food Programme (WFP) and the UN system in general come across as highly complicit in downplaying the problem. OXFAM International is heavily criticized by Tony Vaux, former head of emergencies for OXFAM, in his book The Selfish Altruist (2001), which chronicles the failure of the country representative in Ethiopia to respond to the situation urgently for ideological reasons-both a desire to focus on long-term development rather than respond to emergencies and a reluctance to criticize the Derg government because of his ideological sympathy with the communist cause.

In the aftermath of the famine, a number of different policy and program approaches were adopted. These included improving the early warning system and the logistics of moving food and nonfood supplies in response to nutrition,

9. Some NGOs were also doing their best to get the information on the famine out, including Save the Children, which raised a famine alert in January and moved swiftly to set up emergency intensive feeding and medical programs (Gill 2010). See also Gill (1986).

10. Bob Geldof, of the band Boomtown Rats, played an instrumental role in raising awareness of the Ethiopian famine in 1984 (Geldof 2007).

11. The famous line "A hungry child has no politics," which Ronald Reagan used to justify US aid to Ethiopia, was adopted only after the global news story had broken, although the line had first been used by USAID almost one year previously (Teltsch, New York Times, August 19, 1983, as quoted by Arulananthan 2008).

12. Kissi (2005), in his article "Beneath International Famine Relief in Ethiopia," goes so far as to argue that the willingness of the communist regime of Ethiopia to accept aid from the highly anticommunist Reagan administration in the White House was a triumph over their mutual antagonism. Suffice it to say that the world responded, and the Ethiopian government allowed and even facilitated it. 
health, and agricultural rehabilitation needs. Although there was some progress in these areas, even in the difficult and war-ridden final years of the Derg, these efforts were overwhelmed by other factors.

In the postfamine period, the Derg regime needed to reconstruct its image both internally and externally. However, the same old centralized, patronizing, and oppressive thinking still prevailed, and the policies subsequently adopted were disastrous. Zewde $(2002,255)$ writes:

As if to compensate for its initial tardiness, the government then embarked on an ambitious project of resettling peasants from the drought-prone areas of northern and central Ethiopia to the relatively fertile provinces of the west and south-west. On the surface this appeared to be a logical move. In reality, the forcible nature of the resettlement, as well as the effort to combine it with the government's cherished objective of collectivization, made it a highly unpopular move, both at home and abroad.

Following quickly on the heels of resettlement was the even more unpopular villagization program, which grouped scattered households into villages, ostensibly to provide better services that rarely appeared. The relocation from cherished household land was highly unpopular, and "it thereby contributed to the disaffection of a significant portion of the northern peasantry and the advances that guerillas opposed to the regime were able to make in the late 1980s" (Zewde 2002, 255).

\section{After the Derg Regime: Institutional Change and the Somali Food Crisis}

The Ethiopian People's Revolutionary Democratic Front (EPRDF) government came to power in 1991. The EPRDF government understood the role that famine had played in its victory. Unlike in the case of previous governments, the core members of the EPRDF had fought in famine conditions in the northern part of the country. The Tigrayan core of the new government had experienced all three major droughts in the country $(1984,1987$, and 1989), when it had received substantial international assistance to help in the famine-affected "liberated zones" that it had held within Ethiopia. These experiences had shaped a set of beliefs among the core EPRDF members that greatly influenced their thinking regarding food security and humanitarian assistance.

The EPRDF believed that famines resulted from poor government policies and responses, as evidenced by both the imperial and the Derg regimes. They expected the peasant-centered ideology, which the new government professed, to soon overcome vulnerabilities and make famines history.

The new government concluded that the RRC was a powerful Derg-era institution that needed to be brought down to size and turned to the will of the new government. The expectation was that it would ultimately become un- 
necessary. Furthermore, the EPRDF deduced that humanitarian assistance could be used for subversive purposes (as it had been when the TPLF was supported) or to prop up hostile regimes (as it had been when used to support the Derg); thus NGOs could not be trusted. On the other hand, the EPRDF government found UN organizations weak and oriented to the needs of their client governments, which made them compliant partners. Thus, from 1991-95 the Transitional Government brought in a variety of new policies and strategies regarding emergency preparedness and response. These included dismantling the RRC, significantly reforming the strategic food reserves programs, launching the Productive Safety Net Programme, and restructuring the Disaster Prevention and Preparedness Commission.

\section{Post-Derg Era Policies}

As the RRC became politicized near the end of the Derg regime, the core of the EPRDF embarked on a series of drastic reforms that included a variety of new policies and strategies regarding emergency preparedness and response, capped by the 1993 National Policy on Disaster Prevention and Management (NPDPM). This was a state-of-the-art policy formulated by government and foreign experts that built on the National Disaster Prevention and Preparedness strategy that had been drafted, but never adopted, in the dying days of the Derg regime. The NPDPM included an early warning system linking relief to development through community-centered "employment generation schemes" and a section governing the administrative requirements and activities of NGOs. The newly formed Disaster Prevention and Preparedness Commission (DPPC), which replaced the former RRC, was given the mandate to manage the NPDPM with direct responsibility for food aid and coordination of nonfood responses through other government ministries.

Ethiopia was blessed with a series of good rainfall years in the mid-1990s, which gave the impression that the new government policies were eradicating the threat of famine. The large harvest of 1996 suggested to some that the DPPC was no longer needed, and many government officials and members of the international community were eager to close it down. However, rainfall failures in various parts of the country occurred in the spring of 1997, and it became clear that there were problems with the implementation of the NPDPM. On the emergency response side, the DPPC requested and controlled food aid and was considered to be working well. Yet, due to a lack of real administrative authority, the DPPC had no power to coordinate nonfood responses through other departments such as Health and Water. Therefore, the main functions of the DPPC (however flawed) remained early warning and emergency food response.

In August 2008, the DPPC was closed and replaced by the Disaster Risk Management and Food Security Service (DRMFSS), led by a state minister of the Ministry of Agriculture and Rural Development. At the same time, the federal-level staff was reduced to 300 from over 1,000 during the RRC tenure 
and 700 during that of the DPPC (Lautze, Raven-Roberts, and Erkineh 2009). The official position was that the DRMFSS would rely more on decentralized disaster risk reduction and response. The Government of Ethiopia is serious about the implementation of this approach, but it is too early to judge its effectiveness.

\section{Improvements in Early Warning and Emergency Response}

Ethiopia has a long history of early warning (EW) systems. The first such system was established in early 1974 under the imperial regime after the 1972-74 famine and was further developed after the disastrous 1984 drought. With the promulgation of the NPDPM in 1993, the Ethiopian government and its development partners recognized that the EW system needed to be strengthened further.

This proved particularly true during 1997-99, when the EW system was inadequate to elicit a sufficient response to failures of the belg rains in the Wollo area in the north and the Hararghe area in the east. Under the EW system at the time, the number of emergency beneficiaries was identified by local woreda officials, who passed this number on for compilation to zonal-level officials, who in turn passed it to the regional level and from there to the federal level. In early 1999, three woredas in East Hararghe - Fedis, Gursum, and Babile—sent reports to the zonal level that a combined estimate of 200,000 people were affected by failed rains. Zonal officials for East Hararghe assumed that the woreda officials were exaggerating and cut their number in half, to 100,000 , passing this number to regional officials, who in turn cut the figure down to 50,000 . Federal officials did the same, allocating assistance only for 25,000 beneficiaries in the three woredas. ${ }^{13}$ The issue was resolved only by a flood of desperate food seekers who trekked from the three woredas to the main center of Harar, proving the seriousness of the situation.

That same year in South Wollo, government and WFP officials had decided that all food aid would be distributed from May to September, the "hungry season" before the main meher-season harvest. However, for many farmers in this region the main harvest is the belg-season harvest in April, and the hungry period is from November to March. Thus, the restriction on the timing of food aid distribution brought severe hardship to drought-affected households in early 1999 until the policy was reversed and food aid was allowed to be distributed in March.

Major changes in the EW system were not made until after the Somali drought and famine of 1999-2000, in which tens of thousands of children died from malnutrition and measles (Devereux 2000; Salama et al. 2001). In this case, the system failed to generate enough convincing evidence to elicit an adequate response when it was needed in the fall of 1999. Ultimately, it was a BBC documentary on the situation in Gode, a city in Somali region, that finally prompted a response in April 2000.

13. Personal account of the first author based on his work in the area at the time. 
During the drought, the nutritional assessments conducted by NGOs (14 in 1999-2000) lacked a consistent and comparable methodology. Most of the surveys were not undertaken according to the accepted $30 \times 30$ cluster methodology, and of those only 9 percent (six surveys) met the minimum methodological requirements (Spiegel et al. 2004). ${ }^{14}$ Clearly, there was a need for improvement in the nutritional assessment system. Subsequently, the Emergency Nutrition and Coordination Unit recently formed within the DPPC was strengthened through the development of new nutritional guidelines to provide standards and consistency. The guidelines institutionalized the $30 \times 30$ cluster methodology in Ethiopia and contributed to the consistency and comparability of nutritional assessments in the 2002/03 droughts and beyond. The nutritional assessment methodology continues to evolve, with recent analysis working on the different weight-for-height characteristics of many pastoralist communities.

An alternative assessment methodology proposed by UNICEF under the Enhanced Outreach Strategy (EOS) for child food supplementation adopts the weight-for-length and mid-upper arm circumference methodologies for identifying malnourished children, employing local health officials to undertake the measurements. Some measurements using this system have been highly controversial because they indicate very high levels of child malnutrition. However, overall the EOS system has captured areas of malnutrition and provided response through therapeutic food programs on an ongoing basis. On the nutrition response side as well, huge strides have been made since 1999-2000. Two assessments were undertaken on therapeutic feeding (Collins 2001; Stevens 2003). Major concerns of these assessments are that (1) the technical requirements for outpatient therapeutic care (OTC) were onerous and difficult to scale up sufficiently during a major emergency, (2) the gathering of children and mothers in therapeutic centers increased the spread of disease (in this case, a measles outbreak), and (3) the expense of therapeutic feeding made it difficult to reach large caseloads of patients.

Save the Children UK and other NGOs tried an alternative to OTC in 2000 called community therapeutic feeding (CTF), which involved leaving children and mothers in their communities if possible or meeting them on a scheduled basis to provide ready-to-use therapeutic foods to malnourished children. This was positively reviewed as addressing all of the major problems identified earlier and considered a good approach for managing acute malnutrition in

14. The $30 \times 30$ cluster survey consists of two-stage sampling. In the first stage, a population is grouped into small geographical units (or clusters). Clusters are chosen proportional to the population size; the recommended number is 30 . The second stage involves selection of households and then children for anthropometric measurements; again the recommended number of children is 30 . The choice of 30 clusters hinges on statistical considerations for stability and distribution of means and proportion; the choice of 30 children per cluster is dictated by the number of children necessary for sufficient precision and the number who can reasonably be measured in one day (Spiegel et al. 2004). 
emergencies (Grobler-Tanner and Collins 2004). CTF has since been widely adopted in Ethiopia and has become the main approach to combat malnutrition, complemented by OTC when needed.

Save the Children UK-working closely with the regional government and with the support of the United States Agency for International Development (USAID), the EU, the WFP, and others-launched a Household Economy Analysis-based early warning system specifically for the Somali region in the aftermath of the crisis. This system was running in time for the 2002-03 droughts and yielded a timely food aid and therapeutic feeding response that prevented any measurable excess mortality (OCHA 2003). To better understand and anticipate the severe effects of production shocks on food security, the Livelihoods Integration Unit was incorporated within the Ministry of Agriculture and Rural Development as part of the government's EW system. Under this new approach, baseline data were collected on the income and food consumption patterns of low-, middle-, and high-income groups of households, including the most food insecure. Disaggregating data by livelihood zones allows analysis of household food security that can identify problems that may not be captured in regional analyses. For example, the impacts of production losses of enset and sweet potatoes in 2008 on some households would not have been identified in a timely manner without disaggregated data that identify regional pockets of food-insecure areas. ${ }^{15}$

Improved information flows, as well as enhanced national and regional capacity for monitoring emerging food insecurity patterns over space, have improved the country's capacity for early warning and response planning. A more decentralized response system (via joint government and international organizational planning and regional logistics arrangements) has improved the timeliness of responses to serious hunger threats before they evolve into dire famine conditions.

\section{The Emergency Food Security Reserve}

The establishment of a strategic grain reserve was first recommended by an FAO study in $1974 .{ }^{16}$ The central rationale was that stocks managed by parastatals proved inadequate to address fast-hitting emergencies. A key challenge in such emergencies is that procurement of food, food aid, or commercial imports require at least three to four months of lead time. In the case of food aid, there are two lead times: one is the time elapsed between pledge and actual commitment, and the other is the time needed to deliver the food to the beneficiaries after the donors make the commitment. Thus, both the Ethiopian government and its development partners were convinced that the country needed to

15. Data from the Livelihoods Integration Unit on consumption patterns of pastoralists are presented in Chapter 7.

16. This section relies heavily on Rashid and Lemma (2010). 
have an emergency food stock that could feed the vulnerable population for at least four months.

A follow-up study launched by the FAO in 1979 recommended building up a stock of 180,000 tons within four years. This recommendation resulted in the establishment of the Emergency Food Security Reserve Administration (EFSRA) in 1982 as an additional unit attached to the RRC. Subsequently, a joint study conducted by the WFP and the Overseas Development Administration of the United Kingdom recommended revising the stock level upward to 204,600 tons in 1987. Under the transitional government, the EFSRA went through a significant institutional change in October 1992, with the EFSRA becoming an autonomous agency and important changes made in the operational modalities. After the emergencies of 2003, the reserve level was reevaluated and a new stock level of 407,000 tons was established in 2004. The increase was largely dictated by the increase in the vulnerable population in the country and the assumption that it would take four months to bring a new shipment of food to the country.

The EFSRA is credited for effectively addressing several emergencies since the early 1990s. According to a FAO study conducted for the New Economic Partnership for Africa's Development, the national food security reserves played a key role in handling the 1994 emergency by releasing 94,000 tons of food to NGOs and another 52,000 tons of free draw-down by government relief agencies; the EFSRA was the only immediate source of supplies during the 1997 belg crop failures and the 1999-2000 droughts (FAO 2004). Likewise, Rashid and Lemma (2010) conclude that the EFSRA has managed grain reserves in a cost-effective way. The study identified three key factors behind this success. First is the institutional design of the EFSRA, reflecting a very high level of commitment from both the government and its development partners. Chaired by the head of the DRMFSS, the EFSRA board consists of the EFSRA manager and representatives from the Ministries of Finance, Agriculture, and Rural Development, as well as the Ministry of Trade. At a second level is a technical committee that consists of the general manager of the EFRSA, representatives from the Ethiopian Grain Trading Enterprise and the WFP, and a representative of the national and international NGOs engaged in emergency operations. Although the board is responsible for broad policy guidance, day-to-day operations are generally overseen by the EFSRA general manager in consultation with this technical committee. ${ }^{17}$

The second key factor behind the EFSRA's success is the separation of its operation from food price stabilization policies. Unlike similar agencies in many other countries that have grain reserve programs, the EFSRA does not engage in buying, selling, transporting, or distributing grain. Instead, it serves as a custodian of the grain stock built through donor and government contribu-

17. For detailed operational modalities, see Rashid and Lemma (2010). 
tions. The government's key responsibility is to lend grain to recognized national and international relief organizations, as well as to government agencies engaged in food security operations, under agreed-upon conditions of repayment in a prespecified time frame and locations. As a result, the agency does not have to carry out any monetary transactions or physical transactions of food, which in many instances breed corruption and lead to other inefficiencies. Also, through linkages with social safety nets and other food security programs, the agency has developed an efficient mechanism of stock rotation, resulting in lower waste and costs of stock holdings.

The final factor behind the EFSRA's success is that stocks are kept at a minimum. Although the original target was set at 407,000 tons, the EFSRA has not held a stock larger than 332,000 tons in any given quarter since 2004; the stock averaged only about 240,000 tons during 2004-05 and 135,000 tons during 2007-08 (Table 9.2).

TABLE 9.2 Quarterly average cereal stocks of the Emergency Food Security Reserve Administration (EFSRA), 2004-08 (metric tons)

\begin{tabular}{lcrrr}
\hline Year & Quarter & Wheat & Maize & \multicolumn{1}{c}{ Total } \\
\hline 2004 & 1 & 273,265 & 58,460 & 331,726 \\
& 2 & 226,586 & 47,288 & 273,874 \\
& 3 & 199,976 & 44,292 & 244,268 \\
2005 & 4 & 170,636 & 56,478 & 227,115 \\
& 1 & 109,451 & 57,152 & 166,603 \\
& 2 & 106,473 & 47,859 & 154,333 \\
\multirow{2}{*}{ Average } & 3 & 205,578 & 53,123 & 258,700 \\
2006 & 4 & 210,170 & 61,783 & 271,953 \\
& 1 & 187,767 & 53,304 & 241,072 \\
& 2 & 185,738 & 46,449 & 232,187 \\
& 3 & 128,624 & 46,338 & 174,963 \\
2007 & 4 & 86,528 & 36,128 & 122,656 \\
& 1 & 156,004 & 55,770 & 211,774 \\
& 2 & 164,267 & 59,776 & 224,043 \\
& 3 & 134,939 & 24,282 & 159,221 \\
2008 & 4 & 59,485 & 21,925 & 81,410 \\
& 1 & 98,304 & 70,722 & 169,027 \\
& 2 & 58,926 & 75,791 & 134,717 \\
& 3 & 29,044 & 25,591 & 54,635 \\
& 4 & 6,243 & 1,371 & 7,614 \\
Average & & 35,477 & 17,850 & 53,327 \\
\hline
\end{tabular}

SOURCE: Ethiopia, EFSRA (2008). 
It should be noted that there are differing views as to Ethiopia's management of food reserves in response to incipient food crises. The system failed to alleviate the 1984 famine two years after its establishment, though reserves did play a role in dealing with the crisis of 1987-88 (Jones 1994). Depletion of stocks to very low levels in 1999-2000 and 2008-09 is also cited as a failure of the system. However, other factors have to be considered before coming to such conclusions. For instance, depletion of stocks to only 60,000 tons in 19992000 was not the result of stock mismanagement but rather a consequence of disagreements between the donors and the government. Donors were slow to refill the EFSRA before the emergency because of international disapproval of the war with Eritrea and a questioning of the emergency request figures (Barrett and Maxwell 2005). Likewise, the sharp drawdown of stocks in 2008-09 was not the cause of food price increases but was the consequence of inaccurate crop forecasts as well as macroeconomic factors (overall inflation and shortages of foreign exchange). Moreover, although maintaining a minimum level of stocks is generally desirable, drawing down stocks to meet critical food needs of vulnerable populations may take precedence in some situations.

\section{The Public Food Distribution and Social Safety Net Programs}

After the 1984-85 famine, the international community continued to inject large amounts of assistance into Ethiopia, which arguably prevented the return of famine, particularly in the poor production year of 1987. The massive excess of donations surpassed immediate needs in 1985, providing a "surplus" of food aid that was largely put to use in food-for-work programs. In the aftermath of the famine, most agencies turned their attention to "rehabilitation" and sought to use development activities to safeguard against future famine threats. Free food distribution in normal times was considered a disincentive to food production; providing food in exchange for work was the preferred approach. By 1986-87, when the peak of the crisis had passed in most regions, a public works boom started (Webb and Kumar 1995). The massive results of this public works boom can still be seen in Ethiopia today in the visible terracing on the road from Dire Dawa to Harar.

Under the Transitional Government (1991-95), the Employment Generation Scheme (EGS) was launched as the successor to food-for-work programs. Although pilot programs were successfully launched and agriculture experts and development agents lent their support to public works undertaken by beneficiaries of emergency food, the program was not sustainable or replicable. One of the main reasons for this failure was mismanagement. The EGS was formally under the control of DPPC but relied mainly on the Ministry of Agriculture and Rural Development (MoARD), which had no interest in taking directions from or coordinating with the DPPC. The MoARD never took responsibility for the EGS and never integrated it into their work plans, so the system worked only if an NGO aggressively followed up with government 
officials. (Eventually the EGS was transformed into the Productive Safety Net Programme, directly under the MoARD.)

In 2005, the Government of Ethiopia revised its strategy of distributing food aid and aimed to replace the emergency appeals and ad hoc distribution program with a standing safety net in areas suffering from chronic food insecurity. Since January 2005, the Productive Safety Net Programme (PSNP) has been implemented as part of a broader Food Security Program. The objective of the PSNP is to provide households with enough income (cash or food) to meet their food needs, thereby protecting their households' assets from depletion, and to build community assets to address the root causes of food insecurity. The PSNP delivers cash or food transfers to 7-8 million rural Ethiopians for six months of every year, either through public works ( 85 percent) or-for those chronically food-insecure households whose members cannot work, such as the disabled, elderly, and others (15 percent)—for free as direct support. It is the largest social protection program operating in Sub-Saharan Africa with the exception of South Africa. A detailed program description of the PSNP is provided by Gilligan, Hoddinott, and Taffesse (2009), and a discussion of the targeting of PSNP beneficiaries appears in Chapter 10.

\section{Droughts, Food Insecurity, and Food Aid Inflow}

Despite severe drought-related production shortfalls, Ethiopia has not suffered a major famine causing widespread deaths since 1991. The country has been hit by four large-scale droughts since 1991 that have affected millions of people, but according to the Emergency Event Database of the Centre for Research on Epidemiology and Disaster (CRED), none of them led to largescale deaths as in the past (CRED 2011). In fact, when ranked in terms of total number of affected people, the drought of 2002-03-which affected 12.6 million people - turns out to have been the worst drought in the country's history (Table 9.3). Yet, there were few reported drought-related deaths. By contrast, although only 3 million people were affected by the 1973 drought, there were about 100,000 estimated drought-related deaths. Similarly, although the 2008 drought affected twice as many people (6.4 million) as that of 1973 (3.0 million), there were no reported drought-related deaths.

The policy and institutional reforms described earlier have played a significant role in averting famines or major food security crises in recent years. Targeted and efficient emergency operations, social safety nets, effective coordination across government agencies and their development partners, and emergency food reserves have been central to effectively managing disasters in recent years. For instance, having a large-scale safety net program like the PSNP greatly helped the country in 2008 when a major drought coincided with the global food crisis. However, other factors-such as improvement in infrastructure and information, absence of prolonged civil strife, and relative openness in information sharing - have also played important roles. Due to improve- 
TABLE 9.3 Major droughts and drought-related consequences, 1965-2008

\begin{tabular}{lcc}
\hline & \multicolumn{2}{c}{ Number of deaths and affected people (thousands) } \\
\cline { 2 - 3 } $\begin{array}{l}\text { Year of drought, } \\
\text { by severity }\end{array}$ & $\begin{array}{c}\text { Total } \\
\text { number of deaths }\end{array}$ & $\begin{array}{c}\text { Total } \\
\text { number of people affected }\end{array}$ \\
\hline 1983 & 300 & 7,750 \\
1973 & 100 & 3,000 \\
1965 & 2 & 8,000 \\
1987 & 0.4 & 7,000 \\
1989 & n.a. & 6,500 \\
1999 & n.a. & 4,900 \\
2003 & n.a. & 12,600 \\
2005 & n.a. & 2,600 \\
2008 & n.a. & 6,400 \\
\hline
\end{tabular}

SOURCE: Based on the top 10 list of disasters in Ethiopia since 1900 of the Centre for Research on Epidemiology and Disaster (CRED 2011).

NOTES: The table is sorted by total number of deaths and then chronologically by year. n.a. $=$ not available.

ments in infrastructure and information, the response time of the government and its development partners was much shorter in recent years compared to the past. In addition, carrying out emergency operations has become much easier in the absence of civil strife. Note that the conflict with Eritrea (May 1998-June 2000) was largely confined to the borders and had little direct influence on most households in what is now Ethiopia.

Although the country has managed to avert widespread famine since 1991, localized food shortages continue to be a recurrent phenomenon. Food aid has been one of the key instruments for dealing with these emergencies. Historically, Ethiopia has featured prominently as a large recipient of food aid. In 2008, the amount of food aid received in Ethiopia expressed as a percentage of total domestic consumption was quite high (del Ninno, Dorosh, and Subbarao 2007). Although food aid as a share of domestic consumption declined to zero in India, 1.9 percent in Bangladesh, and 3.8 percent in Zambia, it remained at 5.0 percent in Ethiopia in 2008.

There are three reasons for the decline in food aid. First, as shown in Table 9.4, food aid inflow to the country has fluctuated widely, with substantially greater inflow during the drought years until 2005. This was true in 1999-2000 and again during 2002-03. However, this was not the case during 2008-10, when the domestic prices of cereals skyrocketed. In this instance, the market price inflation was to some extent mitigated by government imports, a reintroduction of rationing systems, and perhaps more importantly a depletion of the strategic grain reserves (Dorosh and Ahmed 2009). Second, accord- 
TABLE 9.4 Food production and food aid in Ethiopia, 1996-2008

\begin{tabular}{cccccc}
\hline Year & $\begin{array}{c}\text { Total cereal } \\
\text { production } \\
\text { (thousands of } \\
\text { metric tons) }\end{array}$ & $\begin{array}{c}\text { Total cereal } \\
\text { consumption } \\
\text { (thousands of } \\
\text { metric tons) }\end{array}$ & $\begin{array}{c}\text { Total food } \\
\text { aid delivery } \\
\text { (thousands of } \\
\text { metric tons) }\end{array}$ & $\begin{array}{c}\text { Aid as a } \\
\text { percentage of } \\
\text { production }\end{array}$ & $\begin{array}{c}\text { Aid as a } \\
\text { percentage of } \\
\text { consumption }\end{array}$ \\
\hline 1996 & 10,328 & 7,274 & 120 & 1.2 & 1.6 \\
1997 & 10,437 & 7,713 & 548 & 5.3 & 7.1 \\
1998 & 8,103 & 7,983 & 463 & 5.7 & 5.8 \\
1999 & 8,867 & 8,431 & 1,031 & 11.6 & 12.2 \\
2000 & 9,234 & 8,944 & 1,199 & 13.0 & 13.4 \\
2001 & 11,039 & 9,373 & 299 & 2.7 & 3.2 \\
2002 & 10,371 & 9,635 & 1,214 & 11.7 & 12.6 \\
2003 & 11,536 & 9,886 & 947 & 8.2 & 9.6 \\
2004 & 10,627 & 10,235 & 600 & 5.6 & 5.9 \\
2005 & 12,574 & 10,490 & 699 & 5.6 & 6.7 \\
2006 & 14,412 & 10,945 & 504 & 3.5 & 4.6 \\
2007 & 15,573 & 11,376 & 285 & 1.8 & 2.5 \\
2008 & 16,872 & 12,513 & 626 & 3.7 & 6.0 \\
2009 & 17,117 & 17,861 & 1,112 & 7.7 & 7.7 \\
2010 & 18,076 & 18,249 & 1,401 & 9.0 & \\
\hline
\end{tabular}

SOURCES: World Food Programme-Ethiopia for 2005-08; FAO (various years b) for the remainder.

${ }^{\text {a } F o o d ~ a i d ~ r e f e r s ~ t o ~ c e r e a l s ~ o n l y . ~}$

ing to government statistics, the production situation has improved dramatically. As a result, food aid as a share of production has been on the decline since 2004. Finally, introduction of cash transfers under the PSNP and other policy responses discussed earlier have contributed to the decline in food aid imports since 2005.

Deeper policy debate and change are requirements for sustainable responses to food crises. Some of the central issues that continue to influence food insecurity are these: (1) landholdings are too small for most farming households to achieve food production self-sufficiency, (2) population increases reduce landholdings further and place intolerable stress on an already fragile natural resource base, (3) already low soil fertility is declining due to intensive cultivation and limited application of yield-enhancing inputs, (4) recurrent droughts add food production shocks to abnormally low yields, and (5) limited off-farm employment opportunities restrict diversification and migration options, leaving people trapped in increasingly unviable agriculture (Devereux 2000). Therefore, although policy developments have contributed to averting a major national famine in Ethiopia, there continues to be room for improvement. Regional and localized food insecurity can still occur, as evidenced by food crises in Somali region in 1999-2000 and regional food insecurity in 2008-09. 


\section{The 1999-2000 Food Security Crisis in Somali Region}

Despite developments in early warning and response in the highlands of Ethiopia, the Somali food crisis of 1999-2000 demonstrated the special challenges and the need for tailored response programs in the pastoralist areas of Ethiopia. Although they represent about 60 percent of the land area and contain over 10 percent of the total population, pastoralist areas are generally remote and neglected; emergency response in these areas has also been poor. However, there has been improvement in identifying and responding to emergencies in the last nine years.

In 1999, successive failures of rain in Somali region weakened the coping mechanisms of pastoralists, who had already suffered price declines because of the 1997 ban on livestock imports from the Horn of Africa into Saudi Arabia and other parts of the Middle East, the largest market for sheep and goats from Somali region. When the rains failed in late 1999, the normally resilient pastoralists, who had survived severe droughts as recently as 1993 without significant outside assistance, were thrown into a devastating food crisis. Thousands of people died, mostly children under five years of age. Although some NGOs rang the alarm, they were generally not believed, and a rancorous debate dragged on for months. Finally, a BBC broadcast on April 4, 2000, showing children dying of hunger elicited a response. But significant food aid did not arrive until the beginning of May; ultimately perhaps 80,000-120,000 children died of malnutrition and measles (Salama et al. 2001; Howe and Devereux 2004).

In assessing the causes of the food insecurity-related deaths, the Government of Ethiopia and the international community recognized that a number of measures had to be in place for the pastoralist regions. These included good EW and nutrition assessment systems, regular and emergency measles vaccination campaigns, and the development of health facilities, as well as better and more efficient emergency response programs for food aid distribution and the administration of therapeutic feeding. Following this assessment in 2001, a group of agencies, led by Save the Children UK and funded by USAID and the EU, worked with the Somali Regional Government to set up an early warning system based on Household Economy Analysis, as described above.

The payoff was immediate. By the time the next drought hit Somali region in 2002-03, the system was sufficiently in place to initiate a response and provide direct emergency assistance to the most affected areas. The EW system has subsequently been used to identify the numbers and locations of emergency beneficiaries on an annual basis. Full sustainability of the program in the government has not yet been achieved, however, due to a high rate of staff turnover and limited budget commitment. A four-year program for the final handover of the system to the Somali Regional Government from Save the Children UK is 
now underway, with the government promising to commit financial resources to the system in its annual budget. ${ }^{18}$

\section{Regional Food Insecurity in 2008-09}

In 2008 , localized droughts in both crop-producing and pastoralist areas caused over 12 million people to need food assistance, including safety net beneficiaries. This was the second-highest number of food-insecure people in any given year in Ethiopia's history. Conditions were exacerbated by high food price inflation. Given that official agricultural production figures indicated a good national harvest and safety nets were in place to protect most of the people who were still vulnerable to shocks, there was a delay in declaring a food emergency. It was only after the media reported escalating food insecurity that a substantial response was launched.

The situation was repeated in early 2009. Although this was a better rainfall year than 2008, there were still many vulnerable areas that were badly hit, and child malnutrition again spiked in many parts of the Southern Nations, Nationalities, and People's Region. Again there were delays in organizing a concerted response, due in part to disagreements over the need for NGOs to assist with therapeutic feeding. ${ }^{19}$ Logistical factors, such as port capacity and internal transportation, continue to complicate relief response. For example, when shiploads of Ethiopian fertilizer and food aid arrived around the same time in 2008, Djibouti port could not off-load both cargoes simultaneously due to a capacity constraint. Because the planting season was approaching, the government prioritized off-loading fertilizer at the cost of a delay in food aid arrival.

\section{Conclusions}

In the past two decades, Ethiopia has avoided widespread famines even though the country has faced droughts that are more severe than the ones that triggered famines in the 1970s and 1980s. Although food shortages played a major role in past famines, various other factors contributed to the severity of famines, including military conflict, poor infrastructure, detrimental economic policies, lack of a specific disaster response strategy, and political considerations related to relief response. Lessons from the famines indicated that there was a need to institutionalize the capacity to identify and respond to emergencies and to co-

18. In addition, substantial improvement in the treatment and prevention of measles was achieved through an emergency measles vaccination campaign during the drought of 2002-03. Vaccination campaigns are extremely difficult to conduct in remote areas, but the coverage rates were sufficient to ward off a measles threat.

19. Based on the first author's fieldwork and personal communications. 
ordinate the efforts of all actors, including aid agencies and the government (von Braun, Teklu, and Webb 1998). Further policy debate is needed on issues that continue to influence food insecurity, such as landholdings, population increases, soil fertility and yield enhancement, and off-farm employment opportunities and migration options (Devereux 2000).

Disaster management is mostly focused on food aid, though the nonfood aid response in emergencies is also essential and needs to be improved. Evaluations of the 2002-03 drought response quite rightly criticized the response for being "food first" oriented and for not focusing enough on nonfood, particularly health, needs (Lautze et al. 2003). An evaluation of the 2002-03 drought response led by the DPPC and the UN Office for the Coordination of Human Affairs also advocated stronger responses in areas outside of food aid, including many areas in which there has since been follow-up, such as livestock, EW systems, and nutrition (OCHA 2003). However, little progress has been made on improved health and water responses, apart from the addition of shopping list-style requests from UN agencies to the appeals from the government. Arguably, disease prevention has been addressed through improvements in vaccination coverage in many parts of the country, but in pastoralist areas it remains problematic.

Climate change may increase weather volatility, and inevitably there will be a severe drought in Ethiopia at some point. Although there have been a few major droughts in Ethiopia since 1983-84, affecting large numbers of people, largescale mortalities have been effectively averted. In part, this reflects more effective EW systems, absence of major conflicts, and better government response to warnings. However, the increasing vulnerability of the growing rural populations means that even minor droughts can affect a much larger number of people than ever before. Although 8 million were affected by the severe drought of 1983, 12.6 million were affected by the relatively minor regional drought of 2003. A major drought now could easily affect 20-25 million rural Ethiopians. The scale of the emergency response needed to deal with an emergency of that scale would be a serious challenge to existing systems. It would require an early acknowledgment of the scale of the problem and extraordinary measures by the international community to avert the calamitous outcomes experienced during past famines. Further, there will be a large and continuing need for public expenditures to support safety net programs and to deal with the regular emergencies.

\section{References}

Africa Watch. 1991. Evil Days: 30 Years of War and Famine in Ethiopia. Washington, DC: Human Rights Watch.

Arulanantham, A. T. 2008. A Hungry Child Knows No Politics: A Proposal for Reform of the Laws Governing Humanitarian Relief and "Material Support" of Terrorism. Washington, DC: American Constitution Society for Law and Policy. 
Barrett, C. B., and D. G. Maxwell. 2005. Food Aid after Fifty Years: Recasting Its Role. Abingdon, Oxon, UK: Routledge.

Bouis, H. E., and L. J. Haddad. 1992. "Are Estimates of Calorie-Income Elasticities Too High?” Journal of Development Economics 39 (2): 333-364.

Collins, S. 2001. "Changing the Way We Address Severe Malnutrition during Famines." Lancet 358 (9280): 498-501.

CRED (Centre for Research on Epidemiology and Disaster). 2011. Emergency Event Database (EM-DAT): International Disaster Database. Brussels, Belgium: CRED, Université Catholique de Louvain. Accessed December 2011. www.emdat.be.

del Ninno, C., P. Dorosh, and K. Subbarao. 2007. "Food Aid, Domestic Policy, and Food Security: Contrasting Experiences from South Asia and Sub-Saharan Africa." Food Policy 32 (4): 413-435.

Devereux, S. 2000. Food Insecurity in Ethiopia. Discussion Paper for DFID. Sussex, UK: Institute of Development Studies.

Devereux, S., and S. Maxwell, eds. 2001. Food Security in Sub-Saharan Africa. London: ITDG Publishing.

de Waal, A. 1997. Famine Crimes: Politics and the Disaster Relief Industry in Africa. Bloomington, IN, US: African Rights and the International African Institute, James Currey, Indiana University Press.

Dorosh, P., and H. Ahmed. 2009. "Foreign Exchange Rationing, Wheat Market Distortions, and Food Security in Ethiopia." Paper presented at the Ethiopian Economics Association's Seventh International Conference, June 26, in Addis Ababa, Ethiopia.

Dorosh, P., E. Schmidt, and A. S. Taffesse. 2010. "From Famine to Food Security in Ethiopia: Recent Progress and Further Steps." Paper presented at the conference From Emergency Aid to Food Security in Ethiopia, organized by Bahir Dar University in collaboration with Wageningen University, April 14-15, in Bahir Dar, Ethiopia.

Eilerts, G. 2009. The USAID FEWS NET Weather Hazards Impacts Assessment for Africa. July 2-8. Accessed December 2011. http://fews.net/docs/Publications/ afr_Jul02_2009.pdf.

Ethiopia, EFSRA (Emergency Food Security Reserve Administration). 2008. Stock Status Bulletin from 2004-2008. Addis Ababa.

FAO (Food and Agriculture Organization of the United Nations). 2004. Establishment of Regional Food Security Reserve Systems in Africa. Implementation of the Comprehensive Africa Agriculture Development Programme (CAADP) of NEPAD. South Africa.

—. Various years a. Food Balance Sheets Database. Accessed December 2011. http://faostat.fao.org/.

—. Various years b. FAO Statistical Database (FAOSTAT). Rome. Accessed December 2011. http://faostat.fao.org.

Geldof, B. 2007. Geldof in Africa. London: Random House UK.

Gill, P. 1986. A Year in the Death of Africa: Politics, Bureaucracy, and the Famine. London: Paladin Grafton.

- 2010. Famine and Foreigners: Ethiopia since Live Aid. London: Oxford University Press.

Gilligan, D., J. Hoddinott, and A. S. Taffesse. 2009. “The Impact of Ethiopia’s Produc- 
tive Safety Net Programme and Its Linkages." Journal of Development Studies 45 (10): 1684-1706.

Grobler-Tanner, C., and S. Collins. 2004. A New Approach to Managing Acute Malnutrition in Emergencies and Beyond. Technical Note 8, June. Dublin, Ireland: Food and Nutrition Technical Assistance.

Howe, P., and S. Devereux. 2004. "Famine Intensity and Magnitude Scales: A Proposal for an Instrumental Definition of Famine." Disasters 28 (4): 353-372.

Jones, S. 1994. "Food Security Reserve Policy in Ethiopia: A Case Study of Experience and Implications." Disasters 18 (2): 140-151.

Kissi, E. 2005. "Beneath International Famine Relief in Ethiopia: The United States, Ethiopia, and the Debate over Relief Aid, Development Assistance, and Human Rights." African Studies Review 48 (2): 111-132.

Lautze, S., A. Raven-Roberts, and T. Erkineh. 2009. Humanitarian Governance in the New Millennium: An Ethiopian Case Study. Humanitarian Policy Group Working Paper, February. London: Overseas Development Institute.

Lautze, S., Y. Aklilu, A. Raven-Roberts, H. Young, G. Kebede, and J. Leaning. 2003. Risk and Vulnerability in Ethiopia: Learning from the Past, Responding to the Present, Preparing for the Future. Addis Ababa, Ethiopia: United States Agency for International Development.

OCHA (Office for the Coordination of Human Affairs-United Nations). 2003. OCHA Annual Report 2003. Accessed December 2011. http://ochaonline.un.org/OCHA Home/AboutUs/OCHAPublications/AnnualReportsArchive/tabid/5952/language/ en-US/Default.aspx.

Ofcansky, T. P., and L. Berry, eds. 1991. Ethiopia: A Country Study. Washington, DC: Federal Research Division, Library of Congress.

Pankhurst, A. 1985. "Social Consequences of Drought and Famine: An Anthropological Approach to Selected African Case Studies." PhD dissertation, University of Manchester, UK.

Pankhurst, R. 1964. "The Old Time Handicrafts of Ethiopia." Ethiopian Observer 8: 221-242.

Rashid, S., and S. Lemma. 2010. Strategic Grain Reserves in Ethiopia: The Rationale, Institutional Design, and Performance. Washington, DC: International Food Policy Research Institute.

Salama, P., F. Assefa, L. Talley, P. Spiegel, A. van der Veen, and C. A. Gotway. 2001. "Malnutrition, Measles, Mortality, and the Humanitarian Response during a Famine in Ethiopia." Journal of the American Medical Association 286 (5): 563-571.

Scholler, H., and P. Brietzke. 1976. "Ethiopia: Revolution, Law, and Politics." African Studien 92. Munich, Germany: Weltforum-Verlag.

Seaman, J., and J. Holt. 1975. "The Ethiopian Famine of 1973-74, Wollo Province." Proceedings of the Nutritional Society 34 (114A).

Sen, A. K. 1981. Poverty and Famines: An Essay on Entitlement and Deprivation. Oxford, UK: Clarendon.

Spiegel, P. B., P. Salama, S. Maloney, and A. van der Veen. 2004. "Quality of Malnutrition Assessment Surveys Conducted during Famine in Ethiopia." Journal of the American Medical Association 292 (5): 613-618.

Stevens, D. 2003. Learning from Nutrition Interventions in Eritrea, Ethiopia, and Kenya. 
Field Exchange (Emergency Nutrition Network) 18. Accessed December 2011. http://fex.ennonline.net/18/learning.aspx.

Vaux, T. 2001. The Selfish Altruist: Relief Work in Famine and War. London: Earthscan. von Braun, J., T. Teklu, and P. Webb. 1998. Famine in Africa: Causes, Responses, and Prevention. Washington, DC: International Food Policy Research Institute.

Webb, P., and S. K. Kumar. 1995. "Food and Cash for Work in Ethiopia: Experiences during Famine and Macroeconomic Reform." In Employment for poverty reduction and food security, ed. J. Von Braun. Washington, DC: International Food Policy Research Institute.

Webb, P., and J. von Braun. 1994. Famine and Food Security in Ethiopia: Lessons for Africa. Washington, DC: International Food Policy Research Institute.

Wolde Giorgis, D. 1989. Red Tears: War, Famine, and Revolution in Ethiopia. Trenton, UK: Red Sea Press.

. 2004. "An Oral History.” The Believer, May. Accessed December 15, 2011. Available at http://www.believermag.com/issues/200405/?read=interview_georgis.

Zewde, B. 2002. A History of Modern Ethiopia: 1855-1991, 2nd ed. Oxford, UK: James Currey. 